\title{
Peran Mediasi Skeptisme Auditor pada Pengaruh Kompleksitas Tugas dan Pengalaman Auditor terhadap Audit Judgement
}

\author{
Novalita Budi Kiswati ${ }^{1}$ \\ Fakultas Ekonomi dan Bisnis \\ Universitas Airlangga, Indonesia
}

\author{
Erina Sudaryati ${ }^{2}$ \\ Fakultas Ekonomi dan Bisnis \\ Universitas Airlangga, Indonesia
}

Surel : novalita.budi.kiswati-2018@feb.unair.ac.id

\section{ABSTRAK}

Penelitian ini bertujuan untuk menganalisis peran mediasi sikap skeptisme auditor pada pengaruh kompleksitas tugas dan pengalaman terhadap audit judgment pada KAP di Kota Surabaya. Penelitian ini merupakan penelitian kuantitatif dengan menggunakan kuesioner sebagai instrumen data penelitian. Populasi penelitian ini adalah auditor dari KAP Surabaya yang terdaftar di IAPI tahun 2020. Pengambilan sampel yang dilakukan berupa purposive sampling, sehingga dikethui jumlah sampel sebesar 45 auditor aktif di KAP Surabaya. Teknik analisis data yang digunakan adalah analisis jalur dan sobel test. Hasil penelitian menjelaskan bahwa kompleksitas tugas dan pengalaman berpengaruh positif terhadap audit judgment melalui sikap skeptis auditor. Hasil ini menjelaskan bahwa auditor yang semakin menunjukkan skeptisme yang lebih tinggi akan dapat mendukung peningkatan kualitas dari audit judgment yang dilakukan meskipun kompleksitas tugas audit semakin berat. Dilain sisi, auditor yang berpengalaman atau tidak berpengalaman dalam melakukan audit akan menunjukkan kualitas audit judgment yang semakin baik ketika mampu menunjukkan sikap skeptisme yang semakin sering.

Kata Kunci: Kompleksitas Tugas; Pengalaman; Sikap Skeptis; Audit Judgment.

\section{The Role of Auditor Skeptic Mediation on the Effect of Task Complexity and Auditor Experience on Audit Judgment}

\begin{abstract}
This study aims to analyze the mediating role of auditor skepticism on the effect of task complexity and experience on audit judgment at KAP in Surabaya. This research is a quantitative study using a questionnaire as the research data instrument. The population of this study were auditors from Public Accountant Office Surabaya who were listed in IAPI in 2020. The sampling technique used was purposive sampling, so that the sample size was 45 active auditors in Public Accountant Office Surabaya.The data analysis technique used was path analysis and sobel test. The results showed that the complexity of the task and experience had a positive effect on audit judgment through the auditor's skepticism. These results explain that auditors who increasingly show higher skepticism will be able to support the improvement of the quality of the audit judgment made even though the complexity of the audit task is getting heavier. On the other hand, auditors who are experienced or inexperienced in conducting audits will show better quality audit judgment when able to show more frequent skepticism.
\end{abstract}

Keywords: Task Complexity; Experience; Skepticism; Audit Judgment.

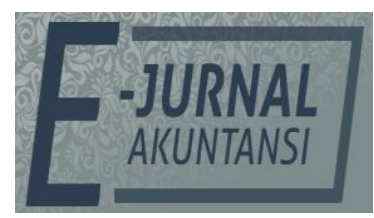

e-ISSN 2302-8556

Vol. 31 No. 4

Denpasar, April 2021

Hal. 1041-1056

DOI:

10.24843/EJA.2021.v31.i04.p19

PENGUTIPAN:

Kiswati, N.B., \& Sudaryati, E. (2021). Peran Mediasi Skeptisme Auditor pada Pengaruh Kompleksitas Tugas dan Pengalaman Auditor terhadap Audit Judgement. E-Jurnal Akuntansi, 31(4), 1041-1056

RIWAYAT ARTIKEL:

Artikel Masuk: 18 Februari 2021 Artikel Diterima: 24 April 2021

Artikel dapat diakses : https://ojs.unud.ac.id/index.php/Akuntansi/index 


\section{PENDAHULUAN}

Kantor Akuntan Publik (KAP) menjadi tempat yang dituju ketika perusahaan go public membutuhkan penilaian atas laporan keuangan yang telah dibuat. Hal ini dikarenakan KAP memiliki kompetensi dan independensi dalam melakukan penilaian laporan keuangan sehingga dapat memberikan kualitas informasi keuangan perusahaan secara tepat dan dapat diandalkan (Idawati \& Eveline, 2017).

Beberapa tahun ini, menunjukkan kondisi yang berbeda mengenai kemampuan KAP dalam memberikan penilaian laporan keuangan perusahaan. Terdapat beberapa kasus yang menunjukkan kegagalan audit sehingga menimbulkan pertanyaan mengenai kapabilitas dan independensi dari KAP dalam melakukan penilaian laporan keuangan perusahaan. Bentuk kasus yang terjadi adalah adanya laporan keuangan perusahaan yang mendapatkan penilaian opini wajar tanpa pengecualian namun mengalami kebangkrutan setelah opimi tersebut dikeluarkan.

Contoh kasus yang terjadi pada PT Asuransi Jiwasraya. Kedua perusahaan diaudit oleh PricewaterhouseCoopers (PwC), dimana PT Asuransi Jiwasraya pada tahun 2017 menunjukkan laba bersih bukan konsolidasi tahun 2016 adlaah 2,1 dengan opini wajar tanpa pengecualian dan laba bersih tahun 2017 sebesar Rp 328 miliar. Nilai yang disajikan di laporan keuangan dan laba komprehensif dinyatakan berdasarkan SAK audited dan dinyatakan telah ditandatangani pada tanggal 29 Juni 2018. Namun pada 10 Oktober 2018, PT Asuransi Jiwasraya mengumumkan tidak mampu membayar klaim polis jatuh tempo sebesar Rp 802 miliar (Lumbanrau, 2019).

Pada tahun yang sama terdapat pula kasus dari PT Sunprima Nusantara Pembiayaan (SNP Finance) yang membobol bank hingga senilai 14 triliun. Kasus ini terjadi karena pihak KAP dari SNP Finance memberikan hasil audit kinerja yang baik sehingga SNP Finance dapat memperoleh pinjaman dari bank untuk menjalankan operasional. Namun ternyata SNP Finance mengalami kesulitan pembayaran kewajiban yang ditunjukkan dengan pengajuan penundaan kewajiban pembayaran utang (PKPU) dengan nilai hutang Rp 4,07 triliun. KAP yang menilai laporan keuangan SNP Finance adalah KAP Satrio Bing, Eny, dan rekan yang kemudian dituntut oleh Bank Mandiri selaku salah satu bank yang menjadi korban, karena KAP tidak melakukan audit dengan sebenarnya (Purnomo, 2018).

Dua kasus yang telah dijelaskan menunjukkan bahwa perlunya pertimbangan yang matang dan cara pandang auditor untuk dapat menanggapi sebuah informasi dalam laporan keuangan perusahaan dan dokumen lain yang mendukung untuk dapat menghasilkan sebuah opini dan judgment yang relevan dan independen. Audit judgment menjadi perihal yang dapat menunjukkan kapabilitas dan independensi KAP dalam melakukan penilaian terhadap laporan keuangan perusahaan.

Audit judgment adalah proses pengambilan keputusan atau kesimpulan dari beberapa solusi alternatif yang memungkinkan dalam kondisi tidak pasti dan berisiko (Popova, 2013). Menurut Hasan \& Andreas (2019), audit judgment adalah pertimbangan yang mempengaruhi keputusan yang diambil auditor. Dengan kata lain, audit judgment merupakan pertimbangan pribadi terhadap 
laporan keuangan yang dipengaruhi oleh bukti dan menghasilkan suatu opini (Xiao, Geng, \& Yuan, 2020). Opini auditor tersebut dapat menentukan kualitas dari laporan keuangan.

Judgment yang semakin baik berdasarkan pada kualitas proses audit yang dilakukan oleh auditor. Sebagaimana dijelaskan oleh Meiryani (2019), pembuatan judgment didasarkan pada informasi yang ada baik kejadian masa lalu, masa sekarang, maupun masa yang akan datang. Judgment harus sesuai dengan bukti dan temuan audit yang ada.

Pada dasarnya prosedur audit telah ditetapkan ketika melakukan perencanaan dan interpretasi dari tiap auditor dalam program audit tersebut tentu akan bervariasi tergantung dari persepsi setiap auditor. Interpretasi ini dapat diwujudkan melalui sikap skeptis auditor. Auditor didalam memberikan opini yang tepat pada laporan keuangan harus memiliki sikap skeptis untuk mengukur tingkat ketepatan dan kebenaran atas bukti maupun informasi dari klien. Sikap yang selalu mempertanyakan kebenaran dari bukti audit yang ada secara kritis merupakan hal yang wajib dilakukan auditor. Hal ini tercantum dalam Standar Profesional Akuntan Publik, SA Seksi 230.

Menurut penelitian yang telah dilakukan oleh Backof, Bamber, \& Carpenter (2016) dijelaskan bahwa tidak semua auditor mampu secara konsisten untuk menjalankan skeptisme dalam proses audit secara baik. Lebih lanjut pada penelitian yang telah dilakukan oleh Sayed Hussin \& Iskandar (2015) menunjukkan bahwa saat ini sikap skeptisme auditor dalam melaksanakan proses auditor semakin berkurang. Pernyataan ini diperkuat dengan temuan kecurangan dari proses audit yang mengalami penurunan. Kecurangan dalam laporan keuangan justru dapat ditemui melalui pengendalian internal perusahaan. Pada penelitian Mohd-Sanusi, Khalid, \& Mahir (2015) menjelaskan bahwa ketika sistem pengendalian internal perusahaan pada kondisi yang baik dan kuat, tidak akan terdapat judgment yang berbeda antara auditor internal perusahaan dengan auditor dari luar perusahaan. Namun pada perusahaan yang memiliki sistem pengendalian internal yang kurang akan terjadi perbedaan judgment antara auditor internal dengan auditor eksternal perusahaan.

Berdasarkan latar belakang yang telah dijelaskan, maka penelitian ini bertujuan untuk menjelaskan peran mediasi dari sikap skeptisme dari auditor pada pengaruh kompleksitas tugas audit dan pengalaman terhadap audit judgment. Hal ini mengacu pada munculnya kasus yang menunjukkan adanya proses audit yang tidak tepat sehingga menyebabkan resiko kerugian pada pengguna informasi laporan keuangan yang telah dinilai oleh auditor dari KAP.

Skeptisisme merupakan perihal mendasar dalam proses audit. Auditor perlu untuk memiliki sikap skeptis selama pelaksanaan proses audit agar dapat menghasilkan informasi yang akurat (Nolder \& Kadous, 2018). Sikap skeptis auditor dapat dijelaskan sebagai sikap yang selalu meragukan dan mempertanyakan segala sesuatu, dan menilai secara kritis bukti audit serta mengambil keputusan audit berlandaskan keahlian auditing yang dimilikinya (Cho \& Taylor, 2020).

Skeptisisme bukanlah sikap sinis, tetapi merupakan sikap yang mengharapkan untuk mempertanyakan, meragukan atau tidak setuju dengan penyajian klien. Penerapan tingkat skeptisisme dalam audit sangatlah penting 
karena dapat mempengaruhi efektifitas dan efesiensi audit. Auditor perlu menerapkan skeptisisme profesional dalam mengevaluasi bukti audit (Zarefar, Andreas, \& Zarefar, 2016). Dengan begitu, auditor tidak menerima bukti audit tersebut apa adanya, tetapi memperkirakan kemungkinan-kemungkinan yang dapat terjadi, seperti bukti yang diperoleh dapat menyesatkan, tidak lengkap, atau pihak yang menyediakan bukti tidak kompeten bahkan sengaja menyediakan bukti yang menyesatkan atau tidak lengkap. Sikap auditor diperlukan ketika auditor berusaha mempertanyakan perihal dalam proses audit, terutama ketika sedang mengumpulkan bukti audit untuk mendukung kesalahan penyajian material (Sayed Hussin \& Iskandar, 2015). Semakin tinggi risiko audit atau semakin besar risiko salah saji material, maka auditor perlu menerapkan skeptisisme profesional yang tinggi juga.

Perihal tersebut juga dijelaskan melalui hasil penelitian yang telah dilakukan oleh Yowanda et al. (2019) bahwa seorang auditor memiliki tanggung jawb untuk memberikan opini yang obyektif dan benar untuk setiap hasil audit yang telah dilakukan. Upaya yang dapat dilakukan untuk mencapai tujuan tersebut adalah melalui proses audit yang dilakukan dengan sikap skeptisisme. Hasil penelitian yang sama juga diungkapkan oleh Pratiwi \& Pratiwi (2020) bahwa sikap skeptis yang ditunjukkan oleh auditor dapat membantu untuk melihat adanya peningkatan risiko dalam proses audit sehingga dapat menentukan pertimbangan yang tepat dalam menentukan opini audit. Maryani \& Ilyas (2017) menambahkan bahwa semakin tinggi sikap skeptis yang ditunjukkan oleh auditor selama proses audit akan meningkan kemampuan auditor untuk mendeteksi kecurangan dan dapat mmberikan audit judgment yang semakin baik. Oleh karena itu dapat dijelaskan bahwa sikap skeptis auditor memiliki pengaruh yang positif terhadap audit judgment.

$\mathrm{H}_{1}$ : Sikap skeptis auditor berpengaruh positif terhadap audit judgment.

Berkaitan dengan kasus yang menunjukkan adanya kegagalan audit pada PT Asuransi Jiwasraya dan SNP Finance, terdapat beberapa hal yang dapat mempengaruhi audit judgment. Salah satunya adalah kompleksitas tugas yang dilakukan oleh auditor. Kompleksitas tugas disusun oleh dua aspek utama, yaitu tingkat kesulitan tugas dan struktur tugas. Tingkat kesulitan adalah terkait dengan banyaknya informasi tentang tugas tersebut, sementara struktur tugas terkait dengan kejelasan informasi (Bonner, 1994). Dengan demikian melaksanakan audit tidak hanya menjalankan program audit yang sudah tersusun secara baik saja, melainkan perlunya pemahaman akan tingkat kesulitan dari proses audit yang akan dilakukan. Mempelajari proses pengumpulan bukti audit merupakan hal yang penting karena komponen utama dalam sikap skeptis seorang auditor adalah penilaian sampai bukti yang cukup dan kompeten telah diperoleh (Wedemeyer, 2010).

Jamilah et al. (2007) menyatakan bahwa manfaat ketika memahami kompleksitas tugas dapat membantu tim manajemen audit perusahaan untuk menemukan solusi terbaik bagi staf maupun tugas audit. Akan tetapi ketika adanya lack of information maka bukti yang didapat akan semakin sedikit dan audit judgment yang muncul tidak maksimal dari auditor tersebut karena sikap skeptis auditor tidak terpatahkan oleh bukti audit yang ada. Untuk itu auditor membutuhkan sikap skeptis dalam melaksanakan tugas audit meskipun tugas 
tersebut memiliki tingkat kesulitan yang tinggi, karena jika auditor hanya menerima informasi yang seadanya tanpa memberikan penilaian kritis terhadap informasi tersebut maka judgment yang diberikan kurang maksimal (Hardiningsih, Januarti, Oktaviani, Srimindarti, \& Udin, 2019).

$\mathrm{H}_{2}$ : Kompleksitas tugas berpengaruh positif terhadap audit judgment melalui sikap skeptisme auditor.

Auditor dalam menghadapi tugas yang kompleks, membutuhkan usaha yang lebih untuk menyelesaikan tugas audit. Auditor harus meningkatkan keahlian dalam mengevaluasi informasi yang didapat dari klien dan tentu harus terus menambahkan pengalamannya. Seperti yang dimukakan Rahayu (2017), auditor yang berpengalaman mempunyai pemahaman dan pengetahuan yang lebih baik atas laporan keuangan. Menurut Widyakusuma et al. (2019) menyatakan bahwa pengalaman akan mengurangi pengaruh informasi yang tidak relevan dalam judgment auditor.

Pengalaman auditor dalam mengaudit dapat menjadi salah satu faktor yang mempengaruhi sikap skeptis auditor karena auditor yang berpengalaman dapat mendeteksi kecurangan dalam laporan keuangan. Hal ini disebabkan karena auditor yang berpengalaman lebih memiliki sikap skeptis daripada auditor yang belum berpengalaman. Auditor yang berpengalaman akan lebih mudah menjalankan kode etik sebagai auditor dalam membuat suatu judgment (Johari, Sanusi, Isa, \& Ghazali, 2014).

Rahayu (2017) mengatakan bahwa auditor yang berpengalaman lebih mendominasi untuk berbuat kesalahan daripada auditor yang belum berpengalaman. Dalam diamond fraud dijelaskan terdapat empat kecenderungan dalam melakukan fraud salah satunya yaitu capability, disini memungkinkan auditor yang sudah berpengalaman dan memiliki pengetahuan lebih dapat melakukan kecurangan. Pengalaman dapat diukur berdasarkan dengan lamanya bekerja seorang auditor dalam melaksanakan tugas auditnya dengan dihitung berdasarkan waktu. Semakin lama waktu yang telah ditempuh seorang auditor dalam melaksanakan tugas audit maka dapat dikatakan sebagai auditor yang berpengalaman.

$\mathrm{H}_{3}$ : Pengalaman auditor berpengaruh positif terhadap audit judgment melalui sikap skeptisme auditor.

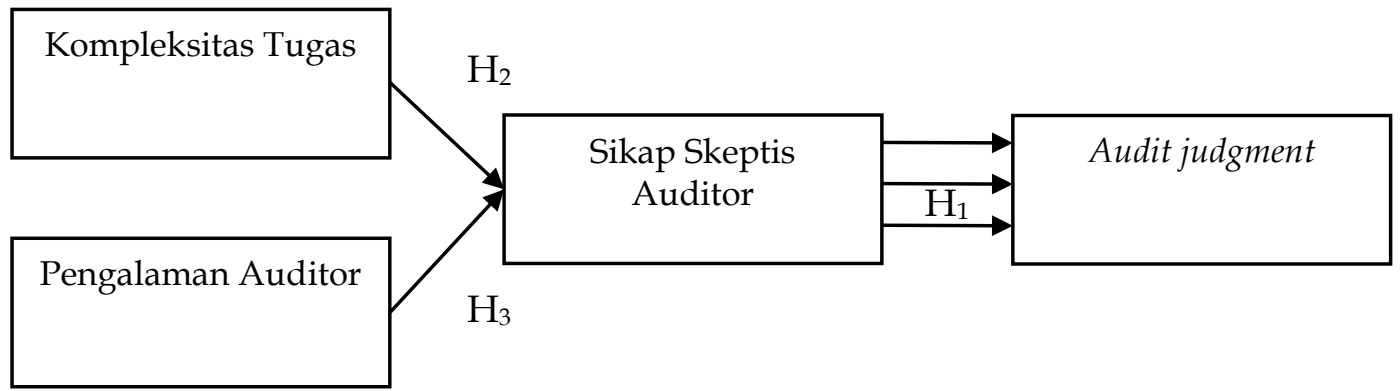

Sumber: Data Penelitian, 2021

\section{Gambar 1. Model Penelitian}




\section{METODE PENELITIAN}

Definisi operasional untuk setiap variabel penelitian dapat dijelaskan sebagai berikut.

Kompleksitas tugas didefinisikan sebagai bentuk tugas yang tidak terstruktur dan sulit untuk diselesaikan oleh auditor (Jamilah et al., 2007). Pengalaman auditor didefinisikan sebagai kemampuan untuk mempelajari setiap kejadian di masa lalu yang berkaitan dengan profesi auditor (Anggreini \& Rasmini, 2017). Sikap skeptis auditor didefinisikan sebagai sikap kritis untuk menilai setiap bukti dalam proses audit (Sari, Wirakusuma, \& Ratnadi, 2018). Audit judgment adalah pertimbangan auditor sebelum mengambil keputusan hasil audit (Jamilah et al., 2007)

Tabel 1. Ringkasan Indikator Variabel Penelitian

\begin{tabular}{|c|c|}
\hline Variabel & Indikator \\
\hline Kompleksitas & 1. Paham mengenai tugas yang harus dikerjakan \\
\hline \multirow[t]{4}{*}{ Tugas $(\mathrm{X} 1)$} & 2. Mengetahui jelas tugas dapat diselesaikan \\
\hline & 3. Terdapat tugas yang membingungkan \\
\hline & 4. Tidak mengerti mengenai tugas yang diberikan. \\
\hline & (Jamilah et al., 2007) \\
\hline Pengalaman & 1. Pengalaman kerja yang selalu bertambah \\
\hline \multirow[t]{7}{*}{ Auditor (X2) } & 2. Pengalaman berguna untuk menyelesaikan audit \\
\hline & $\begin{array}{l}\text { 3. Mengetahui prosedur audit seiring frekuensi melakukan } \\
\text { audit }\end{array}$ \\
\hline & $\begin{array}{l}\text { 4. Paham dengan karakter auditee karena sering bertemu } \\
\text { auditee }\end{array}$ \\
\hline & 5. Mengurangi kesalahan karena terbiasa audit \\
\hline & 6. Selalui mengikuti perkembangan profesi auditor \\
\hline & $\begin{array}{l}\text { 7. Mempelajari hasil kebijakan baru yang diperoleh dari } \\
\text { training }\end{array}$ \\
\hline & (Anggreini \& Rasmini, 2017) \\
\hline Skeptis & 1. Menolak informasi yang tidak ada bukti \\
\hline \multirow[t]{6}{*}{ Auditor (Z) } & 2. Mempertimbangkan dulu sebelum memutuskan \\
\hline & 3. Mempertimbangkan informasi baru yang diterima \\
\hline & Tertarik dengan alasan orang melakukan sesuatu \\
\hline & 5. Memiliki kepercayaan diri \\
\hline & 6. Berpikir panjang untuk menerima informasi baru \\
\hline & Bari et al., 2018) \\
\hline \multirow[t]{3}{*}{$\begin{array}{l}\text { Audit Judgement } \\
(\mathrm{Y})\end{array}$} & $\begin{array}{l}\text { 1. Mencegah auditee untuk merubah catatan akuntansi yang } \\
\text { telah diproses audit }\end{array}$ \\
\hline & $\begin{array}{l}\text { 2. Patuh dengan atasan untuk menunjukkan pelanggaran } \\
\text { yang dilakukan }\end{array}$ \\
\hline & $\begin{array}{l}\text { 3. Menyampaikan hasil audit apa adanya } \\
\text { (Jamilah et al 2007) }\end{array}$ \\
\hline
\end{tabular}

Sumber: Data Penelitian, 2021

Pendekatan penelitian ini adalah pendekatan kuantitatif dengan menggunakan populasi yang merupakan auditor KAP Kota Surabaya yang terdaftar di IAPI. Berdasarkan direktori kantor akuntan publik dan akuntan publik periode 2020 dari IAPI, jumlah KAP di Kota Surabaya adalah 47 KAP. Namun setelah dilakukan penyebaran kuesioner, hanya terdapat 26 KAP yang menolak dan terdapat $12 \mathrm{KAP}$ yang tidak mengembalikan kuesioner. Sehingga terdapat $9 \mathrm{KAP}$ yang bersedia untuk mengisi dan mengembalikan kuesioner. 
Penelitian ini menggunakan auditor sebagai responden penelitian, sehingga dari $9 \mathrm{KAP}$, jumlah auditor yang menjadi sampel penelitian sebesar 45 auditor. Auditor yang menjadi sampel penelitian merupakan auditor yang aktif bekerja, baik sebagai rekan, auditor senior, ataupun auditor junior. Oleh karena itu, pengambilan sampel pada penelitian ini menggunakan purposive sampling. Prosedur pengumpulan data penelitian menggunakan survei melalui kuesioner. Penilaian atas tanggapan dari responden penelitian menggunakan Skala Likert 14 dengan menghilangkan pilihan jawaban ragu-ragu dengan tujuan untuk memperoleh tanggapan yang pasti dari responden tanpa ada keraguan.

Uji validitas dan uji reliabilitas menjadi langkah analisis data yang pertama dilakukan untuk dapat menentukan kemampuan indikator atau instrumen penelitian dalam menjelaskan variabel yang diteliti. Kriteria yang digunakan dalam uji validitas adalah korelasi Pearson dengan nilai kritis lebih besar dari (>) 0,3 (Ghozali, 2008). Pada uji reliabilitas, kriteria yang digunakan adalah nilai Cronbach Alpha yang lebih besar dari (>) 0,6 (Ghozali, 2008). Setelah itu, analisis data dilanjutkan dengan analisis jalur dan Sobel Test.

\section{HASIL DAN PEMBAHASAN}

Berdasarkan hasil yang ditunjukkan Tabel 2 diketahui bahwa responden pada penelitian ini sebagian besar adalah auditor berjenis kelamin wanita (55,6\%) dengan rentang usia 22 hingga 34 tahun (48,9\%). Sebagian besar auditor juga merupakan auditor senior $(57,8 \%)$ yang telah bekerja selama 1 hingga 3 tahun $(46,7 \%)$.

\section{Tabel 2. Deskripsi Profil Responden Penelitian}

\begin{tabular}{ccc}
\hline Jenis Kelamin & Frekuensi & Persentase \\
Pria & 20 & 44,4 \\
Wanita & 25 & 55,6 \\
Usia & & \\
$20-25$ tahun & 15 & 33,3 \\
$26-34$ tahun & 22 & 48,9 \\
35-44 tahun & 7 & 15,4 \\
45 tahun ke atas & 1 & 2,2 \\
Masa Kerja & & \\
1-3 tahun & 21 & 46,7 \\
4-7 tahun & 20 & 44.4 \\
7 tahun ke atas & 4 & 8,9 \\
Jabatan & & 37,8 \\
Auditor Junior & 17 & 57,8 \\
Auditor Senior & 26 & 4,4 \\
Partner & 2 & 100,0 \\
Total & 45 & \\
\hline
\end{tabular}

Sumber: data penelitian, 2021

Pada hasil analisis deskriptif yang ditunjukkan Tabel 3, diketahui bahwa nilai mean kompleksitas tugas sebesar 2,84 dan nilai standar deviasi 0,33, yang menjelaskan distribusi jawaban responden mengenai kompleksitas cenderung setuju dan serupa. Hasil yang sama juga ditunjukkan pada nilai mean pengalaman, sikap skeptis auditor, dan audit judgment dengan yang memiliki nilai mean secara berturut-turut sebesar 2,68, 3,31, dan 2,87. Nilai mean ini 
menunjukkan distribusi jawaban responden mengenai pengalaman sikap skeptis auditor, dan audit judgment yang cenderung setuju dan dengan nilai standar deviasi yang kecil pada ketiga variabel menunjukkan distribusi jawaban responden yang cenderung serupa atau homogen.

Tabel 3. Statistik Deskriptif Variabel Penelitian

\begin{tabular}{|c|c|c|c|c|c|}
\hline & & $\begin{array}{l}\text { Kompleksitas } \\
\text { Tugas (X1) }\end{array}$ & $\begin{array}{l}\text { Pengalaman } \\
\text { (X2) }\end{array}$ & $\begin{array}{c}\text { Sikap Skeptis } \\
\text { Auditor (Z) }\end{array}$ & $\begin{array}{c}\text { Audit } \\
\text { judgment } \\
(\mathrm{Y})\end{array}$ \\
\hline \multirow[t]{2}{*}{$\mathrm{N}$} & Valid & 45 & 45 & 45 & 45 \\
\hline & Missing & 0 & 0 & 0 & 0 \\
\hline Mean & & 2,84 & 2,68 & 3,31 & 2,87 \\
\hline $\begin{array}{l}\text { Std. } \\
\text { Deviation }\end{array}$ & & 0,33 & 0,56 & 0,47 & 0,46 \\
\hline Minimum & & 2 & 2 & 3 & 2 \\
\hline Maksimum & & 3 & 4 & 4 & 4 \\
\hline
\end{tabular}

Sumber: Data Penelitian, 2021.

Tahap analisis selanjutnya yang dilakukan adalah uji instrumen melalui uji validitas dan reliabilitas. Hasil uji validitas menunjukkan bahwa indikator yang digunakan pada variabel kompleksitas tugas adalah 4 indikator memiliki nilai pearson correlation $>0,3$. Hasil yang sama juga ditunjukkan pada indikator dari variabel pengalaman sejumlah 7 indikator, sikap skeptis auditor yang memiliki 18 indikator, dan audit judgment yang memiliki 6 indikator, yang menunjukkan nilai pearson correlation $>0,3$. Secara keseluruhan hasil uji validitas menyatakan nilai ditunjukkan nilai pearson correlation $>0,3$ yang artinya indikator lolos uji validitas dan layak digunakan.

Pada Tabel 4, menunjukkan nilai Cronbach alpha variabel kompleksitas tugas, pengalaman auditor, sikap skeptis auditor, dan audit judgment yang lebih besar 0,6. Hasil ini menjelaskan bahwa setiap indikator yang digunakan untuk menjelaskan variabel kompleksitas tugas, pengalaman auditor, sikap skeptis auditor, dan audit judgment merupakan indikator yang valid dan reliabel.

Tabel 4. Hasil Uji Reliabilitas

\begin{tabular}{lccc}
\hline \multicolumn{1}{c}{ Variabel } & Nilai Cronbach Alpha & Nilai Kritis & Keterangan \\
\hline Kompleksitas Tugas (X1) & 0,757 & 0,6 & Reliabel \\
Pengalaman Auditor (X2) & 0,847 & 0,6 & Reliabel \\
Sikap Skeptis Auditor (Z) & 0,948 & 0,6 & Reliabel \\
Audit Judgement (Y) & 0,853 & 0,6 & Reliabel \\
\hline
\end{tabular}

Sumber: Data penelitian, 2021.

Penelitian menggunakan analisis jalur untuk menjawab hipotesis penelitian. Sebelum uji hipotesis, dilakukan uji asumsi klasik terdiri dari asumsi normalitas, asumsi multikolinieritas, dan asumsi heterokedastisitas. Hasil uji asumsi klasik menunjukkan bahwa nilai signifikansi pada uji kolmogorov smirnov $>$ nilai kritis $5 \%$ atau 0,05 , kemudian pada hasil asumsi multikolinieritas menunjukkan nilai VIF untuk ketiga variabel $<10$ dan nilai tolerance $>$ dari 0,1 , pada hasil uji heterokedastisitas menunjukkan bahwa diagram tidak membentuk pola tertentu dan cenderung menyebar. Berdasarkan hasil uji asumsi klasik tersebut, menjelaskan bahwa model regresi dapat dilanjutkan uji hipotesis. 
Menentukan nilai koefisien dari pengaruh tidak langsung dilakukan dengan menghitung perkalian antara nilai koefisien kompleksitas tugas dan pengalaman auditor terhadap sikap skeptis auditor dengan nilai koefisien sikap skeptis auditor terhadap audit judgment. Analisis jalur yang dilakukan pada penelitian ini menggunakan analisis sobel dengan hasil yang ditunjukkan Tabel 5 , berikut.

\section{Tabel 5. Hasil Uji Hipotesis}

\begin{tabular}{|c|c|c|c|}
\hline Hipotesis & Koefisien & Sig. & Keterangan \\
\hline Sikap skeptis auditor $(\mathrm{Z}) \rightarrow$ audit judgment $(\mathrm{Y})$ & 0,376 & 0,004 & Diterima \\
\hline $\begin{array}{l}\text { Kompleksitas tugas }(\mathrm{X} 1) \rightarrow \text { sikap skeptis auditor }(\mathrm{Z}) \\
\rightarrow \text { audit judgment }(\mathrm{Y})\end{array}$ & 0,186 & 0,023 & Diterima \\
\hline $\begin{array}{l}\text { Pengalaman auditor }(\mathrm{X} 2) \rightarrow \text { sikap skeptis auditor }(\mathrm{Z}) \\
\rightarrow \text { audit judgment }(\mathrm{Y})\end{array}$ & 0,124 & 0,019 & Diterima \\
\hline
\end{tabular}

Sumber: Data penelitian, 2021.

Hasil yang ditunjukkan pada Tabel 5, menunjukkan bahwa sikap skeptis yang ditunjukkan oleh auditor berpengaruh positif terhadap audit judgment. Hasil penelitian juga menunjukkan bahwa kompleksitas tugas dan pengalaman auditor berpengaruh positif terhadap audit judgment melalui sifat skeptisme auditor. Hal ini ditunjukkan melalui nilai koefisien yang bernilai positif dan nilai signifikansi yang lebih rendah dari nilai kritis $5 \%$ atau 0,05 . Hasil yang ditunjukkan pada Tabel 5, juga menunjukkan bahwa hipotesis penelitian yang diajukan, baik hipotesis 1, hipotesis 2, dan hipotesis 3 dapat diterima kebenarannya.

Berdasaran hasil analisis diketahui bahwa sikap skeptis yang ditunjukkan oleh auditor selama melakukan proses audit berpengaruh positif terhadap audit judgment. Hasil ini menjelaskan bahwa semakin tinggi sikap skeptis auditor selama melakukan audit akan membantu untuk mendeteksi adanya kecurangan, sehingga risiko kecurangan pada laporan keuangan akan semakin rendah dan auditor dapat memberikan keputusan audit secara tepat.

Maryani \& Ilyas (2017) menerangkan bahwa bahwa sikap skeptisme yang semakin tinggi akan meningkatkan kemampuan auditor untuk menekan terjadinya kecurangan dalam laporan keuangan, sehingga kualitas audit menjadi lebih baik dan audit judgment yang diberikan menjadi lebih baik. Idawati \& Eveline (2017) menambahkan bahwa seorang auditor memiliki tanggung jawab untuk melaksanakan proses audit dengan tepat. Pada proses audit tersebut, dibutuhkan sikap skepsitisme untuk dapat membantu auditor menetapkan tingkat materialitas laporan keuangan perusahaan dengan tepat.

Pratiwi \& Pratiwi (2020) juga menjelaskan bahwa auditor yang dapat menunjukkan sikap kritis selama proses audit dapat membantu meningkatkan ketepatan dalam melakukan pertimbangan. Dalam hal ini, sikap kritis yang dimaksud adalah menggunakan pengetahuan dan keterampilan secara professional untuk melakukan tugas audit secara cermat sehingga audit judgment yang diberikan auditor semakin tepat (Yowanda et al., 2019).

Hasil analisis yang telah dilakukan juga menjelaskan bahwa kompleksitas tugas berpengaruh positif dan signifikan terhadap audit judgement yang dilakukan oleh auditor melalui sikap skeptisme. Hasil penelitian ini menjelaskan bahwa resiko kompleksitas tugas yang dikerjakan akan dapat diminimalisir 
ketika auditor mampu melakukan pengecekan terhadap setiap informasi dan kejelasan tugas melalui sikap skeptisme yang ditunjukkan sehingga auditor dapat menunjukkan audit judgement yang berkualitas.

Pektra \& Kurnia (2015) menerangkan bahwa kompleksitas dalam proses audit dipengaruhi oleh beberapa faktor, yaitu banyaknya informasi yang tidak relevan dengan kejadian yang telah diprediksi dan adanya keberagaman hasil yang diharapkan oleh klien ataupun atasan dari proses audit yang dilakukan. Untuk dapat menghindari faktor tersebut, dapat dilakukan melalui sikap skeptisme auditor, seperti melakukan identifikasi terhadap setiap informasi yang berkaitan dengan tugas audit yang akan dilakukan.

Heyrani et al. (2016) mengungkapkan bahwa ketika auditor memiliki pemahaman yang baik mengenai tujuan audit yang dilakukan, akan cenderung tetap menjalankan standar audit meskipun mengalami kesulitas yang semakin berat sehingga auditor dalam mengambil judgment yang baik. Sebagaimana dijelaskan dalam hasil analisis deskriptif bahwa auditor di KAP Surabaya memiliki sikap skeptisme yang tinggi, dimana auditor akan berupaya melakukan identifikasi terhadap setiap informasi yang diterima, sehingga resiko kompleksitas tugas dapat diminimalisir dan dapat mendukung tercapainya audit judgement yang baik.

Hasil penelitian selanjutnya menjelaskan mengenai pengalaman auditor yang memiliki pengaruh yang positif terhadap audit judgement melalui sikap skeptisme yang ditunjukkan oleh auditor. Hasil ini menjelaskan bahwa pengalaman auditor akan mampu mendukung sikap skeptisme auditor dalam menjalankan proses audit sehingga audit judgement yang dihasilkan tetap dalam kondisi yang baik.

Pengalaman yang dimiliki oleh auditor dapat menjadi sebuah pertimbangan sebelum melakukan audit judgement, dimana pertimbangan tersebut diwujudkan dalam bentuk sikap skeptis melalui proses identifikasi informasi dan perintah dari atasan untuk tugas audit (Parwatha, Sujana, \& Purnamawati, 2017). Yendrawati \& Mukti (2015) menambahkan bahwa pada dasarnya tugas audit tidak jauh dari tugas audit yang lain, artinya pola dalam proses audit cenderung sama dalam setiap tugas, oleh karena itu pengalaman dapat membantu auditor untuk mengolah sikap skeptisme pada setiap langkah audit, sehingga kualitas informasi dapat terjaga dan dapat mendukung pemberian audit judgement yang baik. Hal ini juga diungkapkan oleh hasil penelitian dari Bahtiar, Pagalung, Habbe, \& Harryanto (2017) yang menjelaskan bahwa pengalaman auditor tidak menjadi perihal yang mempengaruhi kemampuan auditor untuk dapat mendeteksi adanya fraud, namun sikap skeptis yang ditunjukkan dapat meningkatkan kemampuan mendeteksi fraud dari auditor.

Kondisi demikian yang terjadi di KAP Surabaya, dimana mayoritas auditor merupakan auditor senior yang memiliki pengalaman yang cukup, sehingga sikap skeptisme yang ditunjukkan untuk melakukan proses identifikasi informasi dan perihal lain yang mendukung proses audit dapat tetap terjaga secara konsisten. Sehingga proses tersebut dapat menimbulkan audit judgement yang baik dan berkualitas tanpa mengorbankan profesionalisme auditor. Namun pada auditor junior, kondisi demikian belum dapat tercapai karena belum 
memiliki pengalaman mengenai proses audit dan pola audit (Nugraha \& Januarti, 2015).

\section{SIMPULAN}

Hasil penelitian menjelaskan bahwa sikap skeptisme auditor berpengaruh positif terhadap audit judgment yang dilakukan oleh auditor di KAP Surabaya. Hasil ini menjelaskan bahwa auditor yang memiliki sikap skeptis yang tinggi selama melakukan proses audit akan dapat menunjukkan audit judgment yang semakin baik dan tepat. Hasil penelitian juga menjelaskan bahwa kompleksitas tugas berpengaruh positif dan signifikan terhadap audit judgement yang dilakukan oleh auditor di KAP Surabaya melalui sikap skeptisme auditor. Hasil ini menjelaskan bahwa peningkatan sikap skeptisme auditor mampu mendukung peningkatan kualitas audit judgement meskipun terdapat tingkat kompleksitas tugas semakin meningkat. Hasil penelitian juga menjelaskan bahwa pengalaman auditor berpengaruh positif dan signifikan terhadap audit judgement yang dilakukan oleh auditor di KAP Surabaya melalui sikap skeptisme auditor. Hasil ini menjelaskan bahwa peningkatan sikap skeptisme auditor mampu mendukung peningkatan kualitas audit judgement pada auditor yang berpengalaman atau yang tidak berpengalaman.

Implikasi dari penelitian ini adalah pihak pemegang kebijakan di KAP dapat merancang atau mengembangkan model pelatihan yang bertujuan untuk meningkatkan sikap skeptisme auditor. Sehingga dapat meminimalisir resiko dari adanya kompleksitas tugas yang dialami oleh auditor terhadap kualitas audit judgement yang diberikan terhadap laporan keuangan klien. bagi auditor, dapat belajar dan bekerjasama dengan auditor yang lebih berpengalaman untuk mengetahui bagian yang perlu diperhatikan untuk dapat menimbulkan sikap skeptisme auditor yang lebih peka pada situasi yang tertekan secara ketaatan dari klien dan tugas yang semakin kompleks, sehingga dapat menjaga kualitas audit judgement.

Penelitian ini memiliki keterbatasan selama melakukan pengumpulan data, yaitu dari 47 KAP yang terdapat di Surabaya, hanya 9 KAP yang terlibat dalam penelitian ini, dikarenakan terdapat KAP yang menolak dan tidak mengembalikan kuesioner yang diberikan. Pada waktu penyebaran kuesioner ke KAP yang dilakukan pada bulan Desember tahun 2020 bertepatan dengan jadwal kesibukan auditor dan KAP yang tinggi sehingga sebagian KAP menolak atau bahkan tidak merespon untuk menerima kuesioner penelitian.

\section{REFERENSI}

Anggreini, N. W. D., \& Rasmini, N. K. (2017). Pengaruh Pengalaman Auditor Dan Time Budget Pressure Pada Profesionalisme Dan Implikasinya Terhadap Kinerja Auditor. E-Jurnal Akuntansi Universitas Udayana, 18(1), 145-175.

Backof, A. G., Bamber, E. M., \& Carpenter, T. D. (2016). Do auditor judgment frameworks help in constraining aggressive reporting? Evidence under more precise and less precise accounting standards. Accounting, Organizations and Society, 51, 1-11. https://doi.org/10.1016/j.aos.2016.03.004 Bahtiar, Pagalung, G., Habbe, A. H., \& Harryanto. (2017). The Effects of Audit 
Experience, Trust and Information Technology on the Professional Skepticism and Ability in Detecting Fraud by Internal Bank Auditors in Jakarta, Indonesia Gagaring Pagalung. Scientific Research Journal, V(IX), 1-9. Retrieved from www.scirj.org

Bonner, S. E. (1994). A model of the effects of audit task complexity. Accounting, Organizations and Society, 19(3), 213-234. https://doi.org/10.1016/03613682(94)90033-7

Cho, Y. N., \& Taylor, C. R. (2020). The role of ambiguity and skepticism in the effectiveness of sustainability labeling. Journal of Business Research, 120(November 2018), 379-388. https:// doi.org/10.1016/j.jbusres.2019.08.034

Ghozali, I. (2008). Structural Equation Modeling: Metode Alternatif Dengan Partial Least Square (PLS). Semarang: Universitas Diponegoro.

Hardiningsih, P., Januarti, I., Oktaviani, R. M., Srimindarti, C., \& Udin, U. (2019). Determinants of audit quality: An Empirical insight from Indonesia. International Journal of Scientific and Technology Research, 8(7), 570-578.

Hasan, M. A., \& Andreas, A. (2019). A Study Of Audit judgment In The Audit Process: Effects Of Obedience Pressures, Task Complexity, And Audit Expertise: The Case Of Public Accounting Firms In Sumatra-Indonesia. International Journal of Scientific and Technology Research, 8(7), 32-37.

Heyrani, F., Banimahd, B., \& Roudposhti, F. R. (2016). Investigation of the Effect of Auditors' Professionalism Levels on their Judgment to Resolve the Conflict between Auditor and Management. Procedia Economics and Finance, 36(16), 177-188. https:/ / doi.org/10.1016/s2212-5671(16)30029-6

Idawati, W., \& Eveline, R. (2017). Pengaruh Independensi, Kompetensi, Dan Profesionalisme Auditor Terhadap Pertimbangan Tingkat Materialitas Dalam Pemeriksaan Laporan Keuangan. Jurnal Akuntansi, 20(1), 16. https://doi.org/10.24912/ja.v20i1.73

Jamilah, S., Fanani, Z., \& Chandr, G. (2007). Pengaruh Gender, Tekanan Ketaatan, dan Kompleksitas Tugas terhadap Audit judgment. Simposium Nasional Akuntansi 10, 1-30.

Johari, R. J., Sanusi, Z. M., Isa, Y. M., \& Ghazali, A. W. (2014). Comparative Judgment of Novice and Expert on Internal Control Tasks: Assessment on Work Effort and Ethical Orientation. Procedia - Social and Behavioral Sciences, 145, 352-360. https://doi.org/10.1016/j.sbspro.2014.06.044

Lumbanrau, R. E. (2019). Jiwasraya: Dari gagal bayar klaim triliunan rupiah hingga dugaan tindakan curang. Retrieved February 10, 2021, from BBC News website: https://www.bbc.com/indonesia/indonesia50821662\#: :text=Direktur Utama Jiwasraya\%2C Hexana Tri,diperkirakan mencapai Rp49\%2C6 triliun.

Maryani, W., \& Ilyas, F. (2017). Pengaruh Skeptisme, Pengalaman Auditor Dan Self Efficacy Terhadap Audit judgment (Studi Empiris pada Auditor Badan Pengawasan Keuangan dan Pembangunan (BPKP) Perwakilan Provinsi Bengkulu). Jurnal Akuntansi, 7(3), 35-52.

Meiryani. (2019). Due professional care as a moderating variable to independence relationship to audit quality. International Journal of Innovative Technology and Exploring Engineering, 8(10), 3463-3469. https://doi.org/10.35940/ijitee.J9720.0881019 
Mohd-Sanusi, Z., Khalid, N. H., \& Mahir, A. (2015). An Evaluation of Clients' Fraud Reasoning Motives in Assessing Fraud Risks: From the Perspective of External and Internal Auditors. Procedia Economics and Finance, 31(15), 2-12. https:// doi.org/10.1016/s2212-5671(15)01126-0

Nolder, C. J., \& Kadous, K. (2018). Grounding the professional skepticism construct in mindset and attitude theory: A way forward. Accounting, Organizations and Society, 67(March), 1-14. https://doi.org/10.1016/j.aos.2018.03.010

Nugraha, A. P., \& Januarti, H. I. (2015). Pengaruh Gender, Pengalaman, Keahlian Auditor Dan Tekanan Ketaatan Terhadap Auditor Judgement Dengan Kompleksitas Tugas Sebagai Variabel Moderasi Pada Bpk Ri Jawa Tengah. Diponegoro Journal of Accounting, 4(4), 42-52.

Parwatha, I. P. A., Sujana, E., \& Purnamawati, I. G. A. (2017). Pengaruh Tekanan Ketaatan, Kompleksitas Tugas, Dan Pengalaman Kerja Terhadap Audit judgment (Studi Empiris Pada Kantor Akuntan Publik Di Provinsi Bali). EJournal Akuntansi Universitas Pendidikan Ganesha, 8(2), 1-11.

Pektra, S., \& Kurnia, R. (2015). Pengaruh Gender, Kompleksitas Tugas, Tekanan Ketaatan, Pengalaman Auditor Terhadap Audit Judgement. Jurnal ULTIMA Accounting, 7(1), 1-20. https:// doi.org/10.31937/akuntansi.v7i1.79

Popova, V. (2013). Exploration of skepticism, client-specific experiences, and audit judgments. Managerial Auditing Journal, 28(2), 140-160. https://doi.org/10.1108/02686901311284540

Pratiwi, W., \& Pratiwi, D. N. (2020). Pengaruh Pengalaman Auditor, Independensi Auditor, Dan Skeptisme Profesional Terhadap Audit judgment. Current: Jurnal Kajian Akuntansi Dan Bisnis Terkini, 1(2), 239-253.

Purnomo, H. (2018). Ada Apa dengan Deloitte dan SNP Finance? Ini Penjelasannya. Retrieved February 10, 2021, from CNBC Indonesia website: https://www.cnbcindonesia.com/market/20180802101243-17-26563/adaapa-dengan-deloitte-dan-snp-finance-ini-penjelasannya

Rahayu, N. (2017). Pengaruh Pengetahuan Perpajakan, Ketegasan Sanksi Pajak, Dan Tax Amnesty Terhadap Kepatuhan Wajib Pajak. Akuntansi Dewantara, 1(1), 15-30.

Sari, K. G. A., Wirakusuma, M. G., \& Ratnadi, N. M. D. (2018). Pengaruh Skeptisisme Profesional, Etika, Tipe Kepribadian, Kompensasi, Dan Pengalaman Pada Pendeteksian Kecurangan. E-Jurnal Akuntansi Universitas Udayana, 7(1), 29-56.

Sayed Hussin, S. A. H., \& Iskandar, T. M. (2015). Re-Validation of Professional Skepticism Traits. Procedia Economics and Finance, 28(April), 68-75. https://doi.org/10.1016/s2212-5671(15)01083-7

Wedemeyer, P. D. (2010). A discussion of auditor judgment as the critical component in audit quality- A practitioner's perspective. International Journal of Disclosure and Governance, 7(4), 320-333. https://doi.org/10.1057/jdg.2010.19

Widyakusuma, A., Sudarma, M., \& Roekhudin, R. (2019). The Effect of Professionalism and Experience on Audit judgment with Task Complexity as a Moderating Variable. International Journal of Multicultural and Multireligious Understanding, 6(2), 97. https://doi.org/10.18415/ijmmu.v6i2.644 
Xiao, T., Geng, C., \& Yuan, C. (2020). How audit effort affects audit quality: An audit process and audit output perspective. China Journal of Accounting Research, 13(1), 109-127. https:/ / doi.org/10.1016/j.cjar.2020.02.002

Yendrawati, R., \& Mukti, D. K. (2015). Pengaruh Gender, Kompleksitas Tugas, Tekanan Ketaatan, Pengalaman Auditor Terhadap Audit Judgement. Jurnal Inovasi Dan Kewirausahaan, 4(1), 1-8. https://doi.org/10.31937/akuntansi.v7i1.79

Yowanda, V., Kristina, V., Pernando, R., Sherly, Erika, Sitepu, W. R. B., \& Dinarianti, R. (2019). Pengaruh Skeptisme, Pengalaman Auditor, dan Self Efficacy Terhadap Audit Judgement Pada Kantor Akuntan Publik di Medan. Jurnal Ilmiah ESAI Volume, 13(2), 124-140.

Zarefar, A., Andreas, \& Zarefar, A. (2016). The Influence of Ethics, Experience and Competency toward the Quality of Auditing with Professional Auditor Scepticism as a Moderating Variable. Procedia - Social and Behavioral Sciences, 219, 828-832. https://doi.org/10.1016/j.sbspro.2016.05.074

Anggreini, N. W. D., \& Rasmini, N. K. (2017). Pengaruh Pengalaman Auditor Dan Time Budget Pressure Pada Profesionalisme Dan Implikasinya Terhadap Kinerja Auditor. E-Jurnal Akuntansi Universitas Udayana, 18(1), 145-175.

Backof, A. G., Bamber, E. M., \& Carpenter, T. D. (2016). Do auditor judgment frameworks help in constraining aggressive reporting? Evidence under more precise and less precise accounting standards. Accounting, Organizations and Society, 51, 1-11. https://doi.org/10.1016/j.aos.2016.03.004

Bahtiar, Pagalung, G., Habbe, A. H., \& Harryanto. (2017). The Effects of Audit Experience, Trust and Information Technology on the Professional Skepticism and Ability in Detecting Fraud by Internal Bank Auditors in Jakarta, Indonesia Gagaring Pagalung. Scientific Research Journal, V(IX), 1-9. Retrieved from www.scirj.org

Bonner, S. E. (1994). A model of the effects of audit task complexity. Accounting, Organizations and Society, 19(3), 213-234. https://doi.org/10.1016/03613682(94)90033-7

Cho, Y. N., \& Taylor, C. R. (2020). The role of ambiguity and skepticism in the effectiveness of sustainability labeling. Journal of Business Research, 120(November 2018), 379-388. https:// doi.org/10.1016/j.jbusres.2019.08.034

Ghozali, I. (2008). Structural Equation Modeling: Metode Alternatif Dengan Partial Least Square (PLS). Semarang: Universitas Diponegoro.

Hardiningsih, P., Januarti, I., Oktaviani, R. M., Srimindarti, C., \& Udin, U. (2019). Determinants of audit quality: An Empirical insight from Indonesia. International Journal of Scientific and Technology Research, 8(7), 570-578.

Hasan, M. A., \& Andreas, A. (2019). A Study Of Audit judgment In The Audit Process: Effects Of Obedience Pressures, Task Complexity, And Audit Expertise: The Case Of Public Accounting Firms In Sumatra-Indonesia. International Journal of Scientific and Technology Research, 8(7), 32-37.

Heyrani, F., Banimahd, B., \& Roudposhti, F. R. (2016). Investigation of the Effect of Auditors' Professionalism Levels on their Judgment to Resolve the Conflict between Auditor and Management. Procedia Economics and Finance, 36(16), 177-188. https:/ / doi.org/10.1016/s2212-5671(16)30029-6 
Idawati, W., \& Eveline, R. (2017). Pengaruh Independensi, Kompetensi, Dan Profesionalisme Auditor Terhadap Pertimbangan Tingkat Materialitas Dalam Pemeriksaan Laporan Keuangan. Jurnal Akuntansi, 20(1), 16. https://doi.org/10.24912/ja.v20i1.73

Jamilah, S., Fanani, Z., \& Chandr, G. (2007). Pengaruh Gender, Tekanan Ketaatan, dan Kompleksitas Tugas terhadap Audit judgment. Simposium Nasional Akuntansi 10, 1-30.

Johari, R. J., Sanusi, Z. M., Isa, Y. M., \& Ghazali, A. W. (2014). Comparative Judgment of Novice and Expert on Internal Control Tasks: Assessment on Work Effort and Ethical Orientation. Procedia - Social and Behavioral Sciences, 145, 352-360. https://doi.org/10.1016/j.sbspro.2014.06.044

Lumbanrau, R. E. (2019). Jiwasraya: Dari gagal bayar klaim triliunan rupiah hingga dugaan tindakan curang. Retrieved February 10, 2021, from BBC News website: https://www.bbc.com/indonesia/indonesia50821662\#: :text=Direktur Utama Jiwasraya\%2C Hexana Tri,diperkirakan mencapai Rp49\%2C6 triliun.

Maryani, W., \& Ilyas, F. (2017). Pengaruh Skeptisme, Pengalaman Auditor Dan Self Efficacy Terhadap Audit judgment (Studi Empiris pada Auditor Badan Pengawasan Keuangan dan Pembangunan (BPKP) Perwakilan Provinsi Bengkulu). Jurnal Akuntansi, 7(3), 35-52.

Meiryani. (2019). Due professional care as a moderating variable to independence relationship to audit quality. International Journal of Innovative Technology and Exploring Engineering, 8(10), 3463-3469. https://doi.org/10.35940/ijitee.J9720.0881019

Mohd-Sanusi, Z., Khalid, N. H., \& Mahir, A. (2015). An Evaluation of Clients' Fraud Reasoning Motives in Assessing Fraud Risks: From the Perspective of External and Internal Auditors. Procedia Economics and Finance, 31(15), 2-12. https://doi.org/10.1016/s2212-5671(15)01126-0

Nolder, C. J., \& Kadous, K. (2018). Grounding the professional skepticism construct in mindset and attitude theory: A way forward. Accounting, Organizations and Society, 67(March), 1-14. https://doi.org/10.1016/j.aos.2018.03.010

Nugraha, A. P., \& Januarti, H. I. (2015). Pengaruh Gender, Pengalaman, Keahlian Auditor Dan Tekanan Ketaatan Terhadap Auditor Judgement Dengan Kompleksitas Tugas Sebagai Variabel Moderasi Pada Bpk Ri Jawa Tengah. Diponegoro Journal of Accounting, 4(4), 42-52.

Parwatha, I. P. A., Sujana, E., \& Purnamawati, I. G. A. (2017). Pengaruh Tekanan Ketaatan, Kompleksitas Tugas, Dan Pengalaman Kerja Terhadap Audit judgment (Studi Empiris Pada Kantor Akuntan Publik Di Provinsi Bali). EJournal Akuntansi Universitas Pendidikan Ganesha, 8(2), 1-11.

Pektra, S., \& Kurnia, R. (2015). Pengaruh Gender, Kompleksitas Tugas, Tekanan Ketaatan, Pengalaman Auditor Terhadap Audit Judgement. Jurnal ULTIMA Accounting, 7(1), 1-20. https://doi.org/10.31937/akuntansi.v7i1.79

Popova, V. (2013). Exploration of skepticism, client-specific experiences, and audit judgments. Managerial Auditing Journal, 28(2), 140-160. https://doi.org/10.1108/02686901311284540

Pratiwi, W., \& Pratiwi, D. N. (2020). Pengaruh Pengalaman Auditor, 
Independensi Auditor, Dan Skeptisme Profesional Terhadap Audit judgment. Current: Jurnal Kajian Akuntansi Dan Bisnis Terkini, 1(2), 239-253.

Purnomo, H. (2018). Ada Apa dengan Deloitte dan SNP Finance? Ini Penjelasannya. Retrieved February 10, 2021, from CNBC Indonesia website: https://www.cnbcindonesia.com/market/20180802101243-17-26563/adaapa-dengan-deloitte-dan-snp-finance-ini-penjelasannya

Rahayu, N. (2017). Pengaruh Pengetahuan Perpajakan, Ketegasan Sanksi Pajak, Dan Tax Amnesty Terhadap Kepatuhan Wajib Pajak. Akuntansi Dewantara, 1(1), 15-30.

Sari, K. G. A., Wirakusuma, M. G., \& Ratnadi, N. M. D. (2018). Pengaruh Skeptisisme Profesional, Etika, Tipe Kepribadian, Kompensasi, Dan Pengalaman Pada Pendeteksian Kecurangan. E-Jurnal Akuntansi Universitas Udayana, 7(1), 29-56.

Sayed Hussin, S. A. H., \& Iskandar, T. M. (2015). Re-Validation of Professional Skepticism Traits. Procedia Economics and Finance, 28(April), 68-75. https://doi.org/10.1016/s2212-5671(15)01083-7

Wedemeyer, P. D. (2010). A discussion of auditor judgment as the critical component in audit quality- A practitioner's perspective. International Journal of Disclosure and Governance, 7(4), 320-333. https://doi.org/10.1057/jdg.2010.19

Widyakusuma, A., Sudarma, M., \& Roekhudin, R. (2019). The Effect of Professionalism and Experience on Audit judgment with Task Complexity as a Moderating Variable. International Journal of Multicultural and Multireligious Understanding, 6(2), 97. https://doi.org/10.18415/ijmmu.v6i2.644

Xiao, T., Geng, C., \& Yuan, C. (2020). How audit effort affects audit quality: An audit process and audit output perspective. China Journal of Accounting Research, 13(1), 109-127. https:/ / doi.org/10.1016/j.cjar.2020.02.002

Yendrawati, R., \& Mukti, D. K. (2015). Pengaruh Gender, Kompleksitas Tugas, Tekanan Ketaatan, Pengalaman Auditor Terhadap Audit Judgement. Jurnal Inovasi Dan Kewirausahaan, 4(1), 1-8. https://doi.org/10.31937/akuntansi.v7i1.79

Yowanda, V., Kristina, V., Pernando, R., Sherly, Erika, Sitepu, W. R. B., \& Dinarianti, R. (2019). Pengaruh Skeptisme, Pengalaman Auditor, dan Self Efficacy Terhadap Audit Judgement Pada Kantor Akuntan Publik di Medan. Jurnal Ilmiah ESAI Volume, 13(2), 124-140.

Zarefar, A., Andreas, \& Zarefar, A. (2016). The Influence of Ethics, Experience and Competency toward the Quality of Auditing with Professional Auditor Scepticism as a Moderating Variable. Procedia - Social and Behavioral Sciences, 219, 828-832. https://doi.org/10.1016/j.sbspro.2016.05.074 